\title{
DETERMINING ROMANIA'S POSITION IN EUROPE AGCORDING TO THE OPTIMIZED GLOBAL FOOD SECURITY INDEX IN 2018
}

\author{
Cristina Năftanăilă ${ }^{1 *}$, Odi Mihaela Zărnescu ${ }^{2}$, Laurentia Avram³ ${ }^{3}$, \\ Viorica Braga ${ }^{4}$, Robert Dragomir ${ }^{5}$ and Elena Gurgu ${ }^{6}$ \\ ${ }^{1223344) 5}$ Spiru Haret University, Câmpulung, Romania \\ ${ }^{6}$ Spiru Haret University, Bucharest, Romania
}

Please cite this article as:

Năftanăilă, C., Zărnescu, O.M., Avram, L., Braga, V., Dragomir, R. and Gurgu, E., 2019. Determining Romania's Position in Europe According to the Optimized Global Food Security Index in 2018. Amfiteatru Economic, 21(51), pp. 294-312.

\section{Article History}

Received: 30 December 2018

Revised: 6 February 2019

Accepted: 24 March 2019

DOI: $10.24818 / \mathrm{EA} / 2019 / 51 / 294$

\begin{abstract}
This article aims to analyze how the Global Food Security Index (GFSI) has evolved across the European countries for the period 2012-2018. In this respect, we have taken as a starting point the Report of Global Food Security Index 2018 as well as the scientific literature from the main stream of publications focusing on food security. The data presented were analyzed and presented statistically, on the basis of which we prepared tables relevant to the proposed goal. The aim of this research is to determine the most vulnerable countries in terms of food security. We analyzed the evolution of the Global Food Security Index for the period 2012-2018, and the subcategories of indicators underlying the determination of the overall GFSI index score: food affordability, food availability, food quality and safety. We also looked at the adjustment indicator data used to determine the GFSI index, natural resources and adaptability.

The natural resources and adaptive capacity indicator measure the exposure of a country to the impact of a changing climate; its susceptibility to the risks of the natural resources and how a country adapts to these risks. When applied, it acts as an adjustment factor for countries' food security scores.

The originality of the paper is to build a globally optimized index for GFSI to provide a comparative analysis of European countries in terms of food security, highlighting Romania's position in this scientific approach.

The motivation for calculating the optimized global food security index lies in the fact that it has only sub-indicators contributing to significant achievements, and its refining has gone through mathematical processing that led to a more relevant hierarchy.

The indicator categories selected within this article are based on the analysis conducted by the Economist Intelligence Unit, Research Division of The Economist that is the world leader in global business intelligence in the above-mentioned report. On the basis of the analysis we drew conclusions regarding the food security in Romania compared to the European countries.
\end{abstract}

Keywords: food security, global food security index (GFSI),GFSI optimized global index,food availability, food affordability, natural resources, food quality and security.

JEL classification: Q11, Q17, Q18.

*Corresponding author, Cristina Alina Năftănăilă - naftanailacristina@yahoo.com 


\section{Introduction}

Food security is defined as a condition where people have access at all times in terms of physical, social and economic access to the sufficient and nutritious food to meet their needs for a healthy and active life.

Based on the GFSI global index analysis, we can understand the causes of global food insecurity; it also helps us to see our long-term consequences in terms of climate change. The Global Food Security Index is a dynamic model used to quantitatively and qualitatively assess food security in both developed and less developed countries. The index is an interactive model that includes: a score rating of three major categories and a set of subcategories of qualitative and quantitative food security index, and a food price adjustment factor to understand the impact of the change on the degree of risk to food security in each country.

Ensuring food security, both nationally and globally, depends on a number of factors such as: health of the land, potable and ocean water represent the major restriction on the productivity increase; the fertile land, water and productive fishing are increasingly demanding because of population growth, urbanization and the income growth, which are changing consumption, in line with the rising demand for meat and fresh produce that requires more intensive use of resources and the generation of waste in larger quantities; climate change also generates the increase, severity and frequency of drought, floods and storms.

Food security is based on the interconnection capacity of social, economic and biophysical systems to meet people's nutritional needs. Causes of deterioration in food security can lead to armed conflicts, hyperinflation, and failures of certain cultures, which are only some of the factors that can lead to a crisis. For the mentioned reasons, governments should take actions in order to increase the food security of the population.

In the first part of the article, we analyzed food security in European countries using the GFSI index, and in the second part of it we developed the GFSI optimized global index. Finally, we presented the results we reached on the basis of the research conducted and the conclusions that come out of this article.

\section{Review of scientific literature}

From a scientific point of view, at international level, the concept of food safety is defined as "universal and permanent access to the food necessary for an active and healthy life" (Brata, 2008). The notion of food safety has, however, manifested multiple meanings, often being assimilated to overlapping with food security (Hanning et al., 2012). By analyzing this notion, the meaning mutations of the concept over time are highlighted. (Dragoi et al., 2018)

Food security has received much attention in recent years. Crises of the food price from 2007 to 2008 and 2010 have made it clear that, despite the decades of efforts to eradicate hunger and malnutrition, food insecurity is still a significant problem. The relationship between food insecurity and poor health is well documented (Cook and Frank, 2008; Hampton, 2007). Food insecurity affects child health and development due to its effect on nutrition and the additional stress it poses on families (Cook and Frank, 2008). It affects all aspects of physical, mental and psychosocial health and it is a key factor in low weight at birth and poor cognitive development (Cook and Frank, 2008; Kristjansson et al., 2007). Rural development is an essential prerequisite for the formulation and implementation of an 
effective strategy for increasing food security, reducing poverty, and promoting overall economic growth. Natural resources play a strategic role in the rural economy, as a potential source of long-term development and as an essential contributor to a constant food supply (Kristjansson et al., 2007)

In addition, it has become clear that food security is strongly interconnected with other issues, such as global environmental or energy changes (Jeroen, 2015). As Scott (2003) and Zanin et al. (2017) state, food security is a critical component in ensuring the sustainable development of contemporary economies, and any problem triggered by a state has a contagion effect, and it is also spreading to other states. The need to ensure food safety standards is important for all products, whether they are of animal or vegetable origin or industrially processed, irrespective of the production process, the distribution chain or their addressability (Post, 2006; Strauss, 2014). King et al. (2017) argue that without achieving the objectives of food safety and security, the objectives of sustainable development cannot be achieved. In this context, particular attention is given to the organization, classification and management of economic data on food trade and food security (Şerban et al., 2015), and a well-known fact is that of the growing importance of informed decisions based on data accumulated over time to ensure long-term success (Andronie, 2015).

In terms of increasing the level of food security, several factors could be identified that could contribute to this increase, among which the most important is the improvement of population education regarding nutrition and resource management (Kaiser et al., 2015). In addition to formal education, independent learning processes based on metacognition and epistemic knowledge can also be considered (Mustata et al., 2014).

In the opinion of the authors Drăgoi et al. (2018), achieving a sustainable food security requires a global strategy with a close connection of all its components. The solution is not only to maximize agricultural production but also to optimize it and adapt it to environmental, social justice and size of the agricultural holdings. In Romania, studies on food security focus on the same approach to global dimension issues (Chirimbu and Burda, 2013; Gurgu, 2011; Rădulescu and Ioan, 2011; Stroe, Cojanu and Militaru, 2010; Uță, 2009).

Brooks and Place (2019) say that in the future food systems there are difficult challenges such as: population growth, hunger, obesity, pollution, resource depletion, food waste, climate change and changes in jobs.

For example, on the European level in Malta, as shown by document "Food and Nutrition Policy and Action Plan for Malta in 2015-2020” (Government of Malta, 2018), sustainability is a major national challenge due to limited natural water resources, local geological nature, natural features and climate change. A safe, reliable and easily accessible source of water is essential for good health. Inappropriate water supply can limit the productivity.

Another example at a global level is Ethiopia, which is one of the poorest countries in the world, known for its precarious food security. Some areas of the country, such as the extended Afarregion, are overpopulated in relation to their ability to produce food. In addition to the demographic explosion, Ethiopia's climate is another factor for persistent food insecurity. In recent years, yields of crops have increased in Ethiopia, but still have some of the lowest agricultural productivity in Africa. This is a problem for a country where $77 \%$ of the population lives their life in agriculture. Land is at the heart of multiple factors that contribute to lower productivity in Ethiopia. With an average size of 1.2 ha or 
0.5 ha in more vulnerable areas, the agricultural parcels are too small and fragmented to achieve economies of scale or even to feed the family with an average of five people, as shown by document "Assessing the root causes of recent food insecurity in Ethiopia. EU Delegation to Ethiopia, 2018”. (EU Delegation to Ethiopia, 2018).

Global agriculture and the food system in its current form is not sustainable. Agricultural practices cause damage to the environment, such as water pollution and soil degradation, while food is of controversial quality. At the same time, agriculture can be an important supplier of jobs, goods and environmental services. The world population is expected to increase by 2050 to 9.5 billion people. Combined with changing consumer requirements, food security will become a major challenge. There are currently changes at all levels - international, national and sub-national - on food production. These changes require unprecedented efforts to implement socio-economic technologies and strategies, and their implementation will require the setting of precise frameworks for planning and monitoring performance.

Most developed and developing countries have to set clear directions to make changes to their farming systems and food products and to ensure that they become more ecological, economic and social. Although there are countries that have already set sustainable development objectives for their agricultural and food sectors, few countries have now developed a clear understanding of how to make changes in complex and diverse food systems. There are also few researches on the feasibility of long-term profound ways of transformation in the agricultural sector and a lack of information exchange on experience and way ahead of countries, making it difficult to capture the benefits of cooperation (United Nations, 2018).

\section{Analysis of food security in European countries using the GFSI index}

Globally, the Global Food Security Index (GFSI) was created, as a comprehensive indicator that measures the three widely accepted dimensions of food security: food affordability, food availability and food quality and safety. This construction of the GFSI indicator has as a starting point research on the state of food insecurity in the world by institutions such as the Food and Agriculture Organization of the United Nations (FAO) or the International Institute for Food Policy Research (IFPRI). The purpose of this index is to take into account the determinants of food security, focusing debates on practical solutions and nutritional and food policies reforms. Thus, nutritional quality and food safety add to the traditional dimensions, affordability and availability. Changes in food prices are analyzed alongside other macroeconomic factors in order to be a tool for early warning of potential price shocks that can compromise food security.

The GFSI index groups around 25 indicators across the three major dimensions (affordability, availability, quality and safety) using data provided by major international organizations to calculate a score with a maximum value of 100 for each indicator and each dimension. The categories of scores (affordability, availability, quality, safety and natural resources, elasticity are calculated as a weighted average of underlying indicators and are scaled from 0 to 100 where 100 is the highest score.) The overall score for GFSI is calculated by a simple weighted average of the first three categories of scores.

Since its inception, GFSI has become a benchmark in government policy and an investment diagnostic tool in a country. The Global Food Security Index was calculated for 113 countries worldwide. In this paper we will analyze the GFSI evolution in the period of 
2012-2018 for the 26 European countries included in the Report. We developed a common framework to make comparisons of food security between countries, in addition to the global ranking, the individual rankings on affordability, availability, quality and safety.

Next, we will refer to the global food security index and we will analyze individually the indicators which are part of the GFSI global index. In table no. 1 we have the evolution of the global food security index in Europe for the period 2012-2018.

Table no. 1: Evolution of the Global Food Security Index GFSI in Europe for the period 2012-2018

\begin{tabular}{|c|c|c|c|c|c|c|c|c|}
\hline No. & Country & 2012 & 2013 & 2014 & 2015 & 2016 & 2017 & 2018 \\
\hline 1. & Austria & 80.3 & 80.7 & 81.7 & 82.0 & 82.7 & 81.9 & 82.1 \\
\hline 2. & Belarus & 62.5 & 61.8 & 61.6 & 62.5 & 63.5 & 62.8 & 65.7 \\
\hline 3. & Belgium & 79.2 & 79.1 & 78.8 & 79.6 & 80.7 & 80.1 & 80.2 \\
\hline 4. & Bulgaria & 62.7 & 62.6 & 61.8 & 63.3 & 64.5 & 63.8 & 64.5 \\
\hline 5. & Czech Republic & 73.6 & 74.6 & 74.2 & 74.1 & 75.3 & 75.9 & 76.1 \\
\hline 6. & Denmark & 81.5 & 81.0 & 81.4 & 80.1 & 80.9 & 80.6 & 80.9 \\
\hline 7. & Finland & 80.2 & 80.1 & 79.3 & 78.6 & 80.4 & 81.3 & 83.3 \\
\hline 8. & France & 83.9 & 83.4 & 82.1 & 82.5 & 83.4 & 82.5 & 82.9 \\
\hline 9. & Germany & 81.5 & 81.3 & 82.1 & 82.6 & 83.6 & 82.8 & 82.7 \\
\hline 10. & Greece & 74.8 & 71.6 & 72.6 & 71.1 & 72.0 & 71.7 & 71.6 \\
\hline 11. & Hungary & 73.5 & 72.8 & 72.0 & 71.9 & 71.8 & 72.2 & 72.8 \\
\hline 12. & Ireland & 82.6 & 82.1 & 82.7 & 83.9 & 87.1 & 86.7 & 85.5 \\
\hline 13. & Italy & 75.6 & 75.0 & 76.1 & 75.7 & 76.7 & 76.0 & 76.3 \\
\hline 14. & Netherlands & 83.4 & 83.1 & 83.6 & 83.5 & 84.0 & 83.1 & 84.7 \\
\hline 15. & Norway & 81.1 & 80.9 & 81.5 & 81.3 & 81.8 & 81.6 & 82.2 \\
\hline 16. & Poland & 73.4 & 72.3 & 73.1 & 74.0 & 74.1 & 74.2 & 75.4 \\
\hline 17. & Portugal & 79.1 & 78.7 & 79.1 & 79.0 & 80.4 & 79.0 & 79.3 \\
\hline 18. & Romania & 67.1 & 67.1 & 68.4 & 67.7 & 69.4 & 67.9 & 68.9 \\
\hline 19. & Russia & 67.4 & 66.4 & 65.4 & 66.0 & 66.8 & 66.2 & 67.0 \\
\hline 20. & Serbia & 59.7 & 59.9 & 60.0 & 60.0 & 60.9 & 60.4 & 59.8 \\
\hline 21. & Slovakia & 68.9 & 68.5 & 68.1 & 68.8 & 69.6 & 70.0 & 70.3 \\
\hline 22. & Spain & 78.7 & 78.1 & 78.9 & 78.0 & 79.1 & 78.2 & 78.0 \\
\hline 23. & Sweden & 81.2 & 80.7 & 81.0 & 81.2 & 82.4 & 82.0 & 82.2 \\
\hline 24. & Switzerland & 82.6 & 81.7 & 82.8 & 83.1 & 83.9 & 82.9 & 83.5 \\
\hline 25. & Ukraine & 58.5 & 58.4 & 57.6 & 55.5 & 56.2 & 53.9 & 55.7 \\
\hline 26. & United Kingdom & 79.1 & 79.4 & 79.9 & 80.7 & 84.3 & 84.4 & 85.0 \\
\hline
\end{tabular}

Source: The Economist Intelligence Unit, 2018 
According to table no. 1, the countries with the highest score in 2018 were Ireland (85.5 out of 100), United Kingdom of Great Britain (85.0 out of 100), the Netherlands (84.7 points in 100) and Romania registered an index value of 68.9 out of 100 in 2018 . The results of this survey show that countries with an average or low level of revenues registered the highest increase in 2018, indicating an orientation to adopt more effective food security measures. The development of agricultural infrastructure and the increase of production capacity to feed a growing population are considered to be the main reasons for improving the scores of European countries

For the calculation of the food affordability indicator, according to the values presented in table no. 2, the following aspects were considered: food consumption as a share of the household, proportion of population expenditure relative to the poverty line, gross domestic product per capita, agricultural import taxes, presence of food safety - net programs and access to funding for farmers.

Table no. 2: Evolution in terms of affordability of food in Europe for the period 2012-2018

\begin{tabular}{|c|c|c|c|c|c|c|c|c|}
\hline No. & Country & 2012 & 2013 & 2014 & 2015 & 2016 & 2017 & 2018 \\
\hline 1. & Austria & 82.1 & 82.4 & 83.0 & 83.1 & 83.3 & 83.5 & 83.5 \\
\hline 2. & Belarus & 61.0 & 60.8 & 60.9 & 62.2 & 64.8 & 62.8 & 67.6 \\
\hline 3. & Belgium & 80.7 & 80.9 & 81.3 & 81.4 & 81.5 & 81.4 & 81.1 \\
\hline 4. & Bulgaria & 67.5 & 67.0 & 67.5 & 70.5 & 70.6 & 70.2 & 70.1 \\
\hline 5. & Czech Republic & 78.0 & 77.7 & 78.1 & 78.1 & 78.4 & 78.0 & 77.9 \\
\hline 6. & Denmark & 81.7 & 81.8 & 82.3 & 82.5 & 82.7 & 82.6 & 82.5 \\
\hline 7. & Finland & 80.8 & 80.7 & 81.1 & 80.9 & 81.0 & 81.0 & 81.3 \\
\hline 8. & France & 80.2 & 80.1 & 80.6 & 80.7 & 80.8 & 80.6 & 80.5 \\
\hline 9. & Germany & 81.8 & 81.9 & 82.5 & 82.7 & 82.9 & 83.0 & 82.9 \\
\hline 10. & Greece & 76.1 & 72.5 & 72.5 & 69.7 & 69.7 & 69.4 & 69.4 \\
\hline 11. & Hungary & 76.0 & 75.8 & 76.2 & 75.9 & 76.1 & 75.6 & 75.6 \\
\hline 12. & Ireland & 82.2 & 82.3 & 82.6 & 83.1 & 86.4 & 87.2 & 87.8 \\
\hline 13. & Italy & 78.9 & 78.8 & 79.0 & 79.1 & 79.2 & 79.3 & 79.2 \\
\hline 14. & Netherlands & 82.2 & 82.2 & 82.8 & 82.6 & 82.9 & 82.8 & 82.8 \\
\hline 15. & Norway & 78.8 & 78.5 & 79.3 & 79.4 & 78.1 & 78.5 & 79.1 \\
\hline 16. & Poland & 75.1 & 75.4 & 75.9 & 76.1 & 76.3 & 76.2 & 76.4 \\
\hline 17. & Portugal & 77.0 & 76.5 & 76.6 & 76.6 & 76.7 & 76.7 & 76.7 \\
\hline 18. & Romania & 67.5 & 67.6 & 67.8 & 67.9 & 68.1 & 67.3 & 67.5 \\
\hline 19. & Russia & 68.2 & 68.5 & 69.3 & 72.2 & 72.0 & 70.6 & 70.5 \\
\hline 20. & Serbia & 64.4 & 64.0 & 64.4 & 64.3 & 64.2 & 63.5 & 63.2 \\
\hline 21. & Slovakia & 73.6 & 73.5 & 73.9 & 73.9 & 74.1 & 73.7 & 73.6 \\
\hline 22. & Spain & 78.9 & 78.8 & 79.0 & 79.1 & 79.3 & 79.3 & 79.2 \\
\hline
\end{tabular}




\begin{tabular}{|l|c|c|c|c|c|c|c|c|}
\hline No. & Country & $\mathbf{2 0 1 2}$ & $\mathbf{2 0 1 3}$ & $\mathbf{2 0 1 4}$ & $\mathbf{2 0 1 5}$ & $\mathbf{2 0 1 6}$ & $\mathbf{2 0 1 7}$ & $\mathbf{2 0 1 8}$ \\
\hline 23. & Sweden & 81.2 & 81.4 & 81.7 & 81.8 & 82.1 & 82.0 & 82.0 \\
\hline 24. & Switzerland & 82.4 & 80.3 & 82.5 & 82.4 & 82.2 & 81.9 & 82.2 \\
\hline 25. & Ukraine & 57.1 & 57.5 & 57.8 & 57.4 & 57.4 & 55.0 & 54.1 \\
\hline 26. & United Kingdom & 81.2 & 81.3 & 81.9 & 82.0 & 82.4 & 82.8 & 82.6 \\
\hline
\end{tabular}

Source: The Economist Intelligence Unit, 2018

The data presented in table no. 2 show that in 2012-2016 in Romania, the trend was rising for this indicator and in the period 2017-2018 the value of the food affordability indicator was slightly lower.

The food availability indicator (table no. 3) includes the following data: sufficiency of supply, average food supply, and chronic food aid, public spending on the agricultural research, agricultural infrastructure, adequate crop storage facilities, road infrastructure, port infrastructure, agricultural production volatility, political stability, corruption, and urban absorption capacity. In 2018, the highest score of this indicator was achieved by Britain with 88.8 points, the Netherlands and Switzerland with a score of 86.1 points. Romania achieved a score of 68.8 points.

Table no. 3: Evolution in terms of food availability in Europe for the period 2012-2018

\begin{tabular}{|l|c|c|c|c|c|c|c|c|}
\hline No. & Country & $\mathbf{2 0 1 2}$ & $\mathbf{2 0 1 3}$ & $\mathbf{2 0 1 4}$ & $\mathbf{2 0 1 5}$ & $\mathbf{2 0 1 6}$ & $\mathbf{2 0 1 7}$ & $\mathbf{2 0 1 8}$ \\
\hline 1. & Austria & 77.8 & 78.9 & 80.4 & 80.7 & 82.0 & 80.1 & 81.3 \\
\hline 2. & Belarus & 63.3 & 62.1 & 60.6 & 61.6 & 61.5 & 61.7 & 63.4 \\
\hline 3. & Belgium & 76.6 & 76.1 & 74.6 & 76.9 & 79.0 & 77.9 & 79.0 \\
\hline 4. & Bulgaria & 58.0 & 58.3 & 55.7 & 56.8 & 59.3 & 58.0 & 60.0 \\
\hline 5. & Czech Republic & 68.6 & 71.7 & 69.7 & 69.7 & 72.4 & 74.1 & 75.4 \\
\hline 6. & Denmark & 80.0 & 79.4 & 79.7 & 76.7 & 78.4 & 77.7 & 79.0 \\
\hline 7. & Finland & 78.1 & 78.0 & 75.3 & 73.9 & 77.9 & 80.0 & 84.2 \\
\hline 8. & France & 85.4 & 84.9 & 81.1 & 82.1 & 84.0 & 81.9 & 83.8 \\
\hline 9. & Germany & 81.9 & 81.3 & 82.2 & 82.9 & 85.2 & 83.1 & 83.6 \\
\hline 10. & Greece & 69.2 & 65.6 & 67.9 & 66.8 & 68.7 & 68.6 & 69.2 \\
\hline 11. & Hungary & 70.3 & 69.2 & 67.3 & 67.6 & 67.2 & 68.6 & 70.5 \\
\hline 12. & Ireland & 81.4 & 80.4 & 81.7 & 83.8 & 88.1 & 86.5 & 83.6 \\
\hline 13. & Italy & 69.5 & 68.7 & 70.1 & 70.0 & 72.1 & 70.5 & 71.6 \\
\hline 14. & Netherlands & 83.5 & 82.9 & 83.2 & 83.2 & 84.3 & 82.3 & 86.1 \\
\hline 15. & Norway & 82.0 & 82.0 & 82.3 & 81.7 & 84.0 & 83.0 & 84.3 \\
\hline 16. & Poland & 71.3 & 68.9 & 70.0 & 71.6 & 71.8 & 72.1 & 75.0 \\
\hline 17. & Portugal & 77.4 & 76.9 & 77.6 & 77.4 & 80.4 & 77.3 & 78.7 \\
\hline 18. & Romania & $\mathbf{6 3 . 5}$ & $\mathbf{6 3 . 7}$ & $\mathbf{6 6 . 5}$ & $\mathbf{6 5 . 1}$ & $\mathbf{6 8 . 8}$ & $\mathbf{6 6 . 0}$ & $\mathbf{6 8 . 8}$ \\
\hline
\end{tabular}




\begin{tabular}{|l|c|c|c|c|c|c|c|c|}
\hline No. & Country & $\mathbf{2 0 1 2}$ & $\mathbf{2 0 1 3}$ & $\mathbf{2 0 1 4}$ & $\mathbf{2 0 1 5}$ & $\mathbf{2 0 1 6}$ & $\mathbf{2 0 1 7}$ & $\mathbf{2 0 1 8}$ \\
\hline 19. & Russia & 64.4 & 61.9 & 58.4 & 56.8 & 58.8 & 58.7 & 61.0 \\
\hline 20. & Serbia & 54.3 & 54.9 & 56.2 & 56.6 & 58.6 & 58.2 & 57.4 \\
\hline 21. & Slovakia & 65.6 & 64.6 & 63.5 & 64.8 & 66.4 & 67.8 & 69.4 \\
\hline 22. & Spain & 75.6 & 74.7 & 76.4 & 74.0 & 76.3 & 74.2 & 74.9 \\
\hline 23. & Sweden & 79.7 & 78.7 & 78.8 & 79.2 & 81.5 & 80.8 & 81.7 \\
\hline 24. & Switzerland & 83.7 & 83.6 & 83.9 & 84.6 & 86.5 & 84.7 & 86.1 \\
\hline 25. & Ukraine & 57.3 & 56.8 & 54.4 & 52.4 & 53.4 & 50.2 & 53.8 \\
\hline 26. & United Kingdom & 76.1 & 77.0 & 77.6 & 79.4 & 87.1 & 87.2 & 88.8 \\
\hline
\end{tabular}

Source: The Economist Intelligence Unit, 2018

The third indicator of food quality and safety (table no. 4) refers to: dietary diversification, nutritional standards, national nutrition guidelines, national nutrition plan or nutrition strategy, nutrition monitoring and supervision, micronutrient availability, dietary availability of vitamin A, quality protein, food security, and the percentage of the population with access to potable water and the presence of the formal food sector.

Table no. 4: Evolution based on food quality and safety in Europe for the period 2012-2018

\begin{tabular}{|l|c|c|c|c|c|c|c|c|}
\hline No. & Country & $\mathbf{2 0 1 2}$ & $\mathbf{2 0 1 3}$ & $\mathbf{2 0 1 4}$ & $\mathbf{2 0 1 5}$ & $\mathbf{2 0 1 6}$ & $\mathbf{2 0 1 7}$ & $\mathbf{2 0 1 8}$ \\
\hline 1. & Austria & 82.4 & 81.5 & 82.3 & 82.8 & 82.8 & 82.8 & 81.0 \\
\hline 2. & Belarus & 64.1 & 63.5 & 66.1 & 66.0 & 66.0 & 66.0 & 67.1 \\
\hline 3. & Belgium & 82.9 & 82.9 & 84.0 & 82.9 & 82.9 & 82.9 & 81.2 \\
\hline 4. & Bulgaria & 63.8 & 63.4 & 64.2 & 63.5 & 63.5 & 63.5 & 63.2 \\
\hline 5. & Czech Republic & 76.3 & 74.6 & 76.3 & 75.9 & 75.9 & 75.9 & 73.7 \\
\hline 6. & Denmark & 84.9 & 83.4 & 83.8 & 83.4 & 83.4 & 83.4 & 82.3 \\
\hline 7. & Finland & 84.6 & 84.4 & 85.8 & 86.0 & 86.0 & 86.0 & 86.0 \\
\hline 8. & France & 88.7 & 87.4 & 88.4 & 88.7 & 88.7 & 88.7 & 86.5 \\
\hline 9. & Germany & 79.8 & 79.8 & 80.8 & 81.3 & 81.3 & 81.3 & 79.7 \\
\hline 10. & Greece & 87.2 & 85.7 & 85.6 & 86.3 & 86.3 & 86.3 & 83.7 \\
\hline 11. & Hungary & 76.0 & 75.4 & 74.5 & 73.8 & 73.8 & 73.8 & 72.0 \\
\hline 12. & Ireland & 86.9 & 86.7 & 85.9 & 86.0 & 86.0 & 86.0 & 84.8 \\
\hline 13. & Italy & 83.9 & 82.8 & 85.2 & 83.3 & 83.3 & 83.3 & 81.9 \\
\hline 14. & Netherlands & 86.3 & 85.6 & 86.8 & 86.1 & 86.1 & 86.1 & 85.1 \\
\hline 15. & Norway & 84.2 & 83.5 & 84.7 & 85.1 & 85.1 & 85.1 & 84.5 \\
\hline 16. & Poland & 74.6 & 73.8 & 74.4 & 75.1 & 74.9 & 74.9 & 74.1 \\
\hline 17. & Portugal & 89.3 & 89.3 & 89.3 & 89.6 & 89.6 & 89.6 & 87.3 \\
\hline 18. & Romania & $\mathbf{7 6 . 1}$ & $\mathbf{7 5 . 3}$ & $\mathbf{7 5 . 0}$ & $\mathbf{7 4 . 4}$ & $\mathbf{7 4 . 4}$ & $\mathbf{7 4 . 4}$ & $\mathbf{7 2 . 6}$ \\
\hline
\end{tabular}




\begin{tabular}{|l|c|c|c|c|c|c|c|c|}
\hline No. & Country & $\mathbf{2 0 1 2}$ & $\mathbf{2 0 1 3}$ & $\mathbf{2 0 1 4}$ & $\mathbf{2 0 1 5}$ & $\mathbf{2 0 1 6}$ & $\mathbf{2 0 1 7}$ & $\mathbf{2 0 1 8}$ \\
\hline 19. & Russia & 73.7 & 73.7 & 74.5 & 75.7 & 75.7 & 75.7 & 75.2 \\
\hline 20. & Serbia & 62.5 & 63.2 & 59.2 & 58.8 & 59.0 & 59.0 & 57.8 \\
\hline 21. & Slovakia & 66.4 & 66.3 & 66.3 & 66.9 & 66.9 & 66.9 & 64.6 \\
\hline 22. & Spain & 86.7 & 85.8 & 85.8 & 86.2 & 86.2 & 86.2 & 83.6 \\
\hline 23. & Sweden & 85.1 & 84.3 & 85.1 & 85.4 & 85.4 & 85.4 & 83.9 \\
\hline 24. & Switzerland & 80.1 & 79.9 & 80.4 & 80.6 & 80.6 & 80.6 & 79.8 \\
\hline 25. & Ukraine & 65.5 & 64.9 & 65.9 & 59.1 & 61.2 & 61.2 & 65.2 \\
\hline 26. & United Kingdom & 82.0 & 81.1 & 81.1 & 81.0 & 81.0 & 81.0 & 80.4 \\
\hline
\end{tabular}

Source: The Economist Intelligence Unit, 2018

At the top of the ranking in 2018 is Portugal, with a score of 87.3 points, followed by France with 86.5 points and Holland with 85.1 points.

In general, the GFSI in 2018 shows a slight improvement in the global food security. More than $80 \%$ of European countries have rising scores.

Along with these indicators, the GFSI calculation also takes into account the category of natural resources and adaptability, a category that is considered to be an adjustment factor. It serves as an objective through which global food security can be calculated to demonstrate changes in the total score when considering climate and natural resource risks.

For the calculation of the natural resource indicator and the adaptation capacity, the following are taken into account: increase in temperature, drought, flood, storm severity (average annual loss), sea level rise, water, land, soil erosion/organic matter, pasture, forest change, oceans, marine biodiversity, protected marine areas, dependence on food imports and dependence on the natural capital.

Among the strengths of Romania, i.e. indicators with a score of over 75 points, we may list the presence of food safety programs (score 100), access to financing for farmers (score 100), urban absorption capacity (score 100) nutritional standards (score 100), food safety (score 100), the proportion of population below the global poverty line (score 99.1), food loss (score 95.3), sufficiency of supply (score 85.6), agricultural import tariffs (score 81.9).

According to the ranking, Romania has scored a maximum of funding sources for farmers, access to the potable water sources and the network developed by the shops. At the same time, it recorded low scores on production volatility, family income allocated for food purchases and agricultural infrastructure, as there were large differences in agricultural output recorded over the past two decades. In Romania, the GDP per capita is a challenge, with a score of 19.6 points out of a total of 100 .

Depending on the food availability criterion, Romania ranks 21st at the European level according to the GFSI ranking. From the food affordability point of view, Romania ranks $24 \mathrm{th}$, and from the point of view of the quality and safety food it ranks 20th.

Further, for Romania, the score and the difference from the average for each GFSI indicator (tables no. 5, 6, 7, 8) was calculated for Romania to determine the position taken by Romania compared to the recorded average in Europe. In table no. 5, regarding the food availability indicator for Romania, we note that there is sufficient food, in terms of supply and urban absorption capacity, with problems related to agricultural infrastructure and corruption. 
Table no. 5: Food availability indicator for Romania

\begin{tabular}{|c|c|c|}
\hline & Score & \% difference from the average \\
\hline $\begin{array}{c}\text { Sufficiency of supply } \\
\text { Public expenditure on research and development } \\
\text { in agriculture }\end{array}$ & 85.6 & $(+) 28.8 \%$ \\
\hline Agricultural infrastructure & 51.9 & $(+) 9.4 \%$ \\
\hline Volatility of agricultural production & 69.2 & $(-) 6.8 \%$ \\
\hline Risk of political stability & 64.7 & $(-) 17.2 \%$ \\
\hline Corruption & 25 & $(+) 17.9 \%$ \\
\hline Urban absorption capacity & 100 & $(-) 12.6 \%$ \\
\hline Food loss & 95.3 & $(+) 23.1 \%$ \\
\hline
\end{tabular}

Source: The Economist Intelligence Unit, 2018

From the point of view of this criterion, we can see from table no. 6 that Romania has accessed funds for agriculture and has food safety programs. We observe that GDP per capita is 19.6 points and the share of household spending on food consumption registered a score of 43.2 points. The deviation from the average to GDP/capita registered an increase of $2.9 \%$, while the share of expenditures for food consumption registered a decrease of $12.4 \%$.

Table no. 6: Food Affordability Indicator for Romania

\begin{tabular}{|c|c|c|}
\hline & Score & \% difference from the average \\
\hline Food consumption as part of household spending & 43.2 & $(-) 12.4$ \\
\hline The proportion of population below global poverty & 99.1 & $(+) 18.2$ \\
\hline GDP/capita & 19.6 & $(+) 2.9$ \\
\hline Tariffs for agricultural imports & 81.9 & $(+) 6.5$ \\
\hline Presence of food safety programs & 100 & $(+) 34.5$ \\
\hline Access to finance for farmers & 100 & $(+) 37.4$ \\
\hline
\end{tabular}

Source: The Economist Intelligence Unit, 2018

According to the data presented in table no. 7, as strengths we can list the food safety subindicators and nutritional standards, which have achieved a maximum score of 100 points. We note that the deviation from the average is positive for all sub-indicators that were taken into account in determining the score for food quality and safety.

Table no. 7: Quality and food safety indicator for Romania

\begin{tabular}{|c|c|c|}
\hline & Score & \% difference from the average \\
\hline Diversification of diversity & 60,3 & $(+) 4.3$ \\
\hline Nutritional Standards & 100 & $(+) 19.9$ \\
\hline Availability of micronutrients & 55,9 & $(+) 12$ \\
\hline Quality of the protein & 65,7 & $(+) 18.5$ \\
\hline Food safety & 100 & $(+) 19.7$ \\
\hline
\end{tabular}

Source: The Economist Intelligence Unit, 2018 
Starting with 2017, the GFSI introduced a new environmental criterion, highlighting the need to conserve resources, adapt to climate change and approve sustainable agriculture practices. Using information on temperature change, land deforestation and depletion of water resources, this criterion, called natural resources and adaptive capacity, was used to measure the future effects of environment change on European countries.

Introduction of this criterion made the score average of high-income countries to decline more than that of those in other income groups.

We present below (table no. 8) the data on the criterion of natural resources and adaptability, according to which Romania ranked 12th, along with Bulgaria, with a score of 74.7 points.

Table no. 8: Natural resources and adaptation capability for Romania

\begin{tabular}{|c|c|c|c|c|c|}
\hline No. & Score & Country & $\begin{array}{l}\text { Global food } \\
\text { security }\end{array}$ & $\begin{array}{l}\text { Natural resources } \\
\text { and adaptability }\end{array}$ & $\begin{array}{c}\text { Adjusting general } \\
\text { food safety }\end{array}$ \\
\hline 1. & 1 & Switzerland & 83.5 & 78.5 & 79.0 \\
\hline 2. & 2 & Ireland & 85.5 & 69.2 & 78.9 \\
\hline 3. & 3 & Austria & 82.1 & 80.2 & 78.0 \\
\hline 4. & $=4$ & France & 82.9 & 76.0 & 77.9 \\
\hline 5. & $=4$ & Netherlands & 84.7 & 67.9 & 77.9 \\
\hline 6. & 6 & Germany & 82.7 & 75.7 & 77.7 \\
\hline 7. & $=7$ & Sweden & 82.2 & 77.3 & 77.5 \\
\hline 8. & $=7$ & $\begin{array}{l}\text { United Kingdom } \\
\text { of Great Britain }\end{array}$ & 85.0 & 64.8 & 77.5 \\
\hline 9. & 9 & Finland & 83.3 & 71.8 & 77.4 \\
\hline 10. & 10 & Denmark & 80.9 & 81.5 & 77.2 \\
\hline 11. & 11 & Norway & 82.2 & 67.6 & 75.5 \\
\hline 12. & 12 & Portugal & 79.3 & 75.7 & 74.5 \\
\hline 13. & 13 & Belgium & 80.2 & 68.5 & 73.9 \\
\hline 14. & $=14$ & Czech Republic & 76.1 & 80.9 & 72.5 \\
\hline 15. & $=14$ & Spain & 78.0 & 71.9 & 72.5 \\
\hline 16. & 16 & Italy & 76.3 & 74.3 & 71.4 \\
\hline 17. & 17 & Poland & 75.4 & 77.7 & 71.2 \\
\hline 18. & 18 & Hungary & 72.8 & 79.2 & 69.0 \\
\hline 19. & 19 & Greece & 71.6 & 74.6 & 67.1 \\
\hline 20. & 20 & Slovakia & 70.3 & 81.7 & 67.1 \\
\hline 21. & 21 & Romania & 68.9 & 74.7 & 64.5 \\
\hline 22. & 22 & Russia & 67.0 & 73.4 & 62.5 \\
\hline 23. & 23 & Bulgaria & 64.5 & 74.7 & 60.4 \\
\hline 24 & 24 & Belarus & 65.7 & 62.9 & 59.6 \\
\hline
\end{tabular}




\begin{tabular}{|c|c|c|c|c|c|}
\hline No. & Score & Country & $\begin{array}{c}\text { Global food } \\
\text { security }\end{array}$ & $\begin{array}{c}\text { Natural resources } \\
\text { and adaptability }\end{array}$ & $\begin{array}{c}\text { Adjusting general } \\
\text { food safety }\end{array}$ \\
\hline 25. & 25 & Serbia & 59.8 & 69.0 & 55.2 \\
\hline 26. & 26 & Ukraine & 55.7 & 57.5 & 49.8 \\
\hline
\end{tabular}

Source: The Economist Intelligence Unit, 2018

According to the ranking of the natural resources and adaptability, the first place is owned by Slovakia, which manages to adapt to the risks related to the climate and natural resources. Its innovations in resistance mechanisms are of particular interest and highlight the leadership role that smaller countries can play in this regard. Slovakia has managed to develop an early warning mechanism for agriculture, forestry and other sectors in response to rising climate risks.

\section{Building the GFSI optimized global index}

The motivation for calculating the optimized global food security index lies in the fact that it has only sub-indicators contributing to significant achievements, and its refining has gone through mathematical processing that led to a more relevant hierarchy.

The construction of a GFSI optimized global index is based on the selection of four subindicators of the three criteria according to the major effective contribution to achieve the index value according to the GFSI Report of 2018. Thus, in constructing the GFSI optimized global index we took into account the following indicators related to the criterion:

Food affordability with the following sub-indicators:

- consumption of food as a share of household expenditures;

- share of the population below the global poverty line;

- presence of food security programs;

- access to finance for farmers.

Food availability criterion from which we selected sub-indicators:

- sufficiency of the offer;

- agricultural infrastructure;

- volatility of agricultural production;

- food loss.

Quality and safety food criterion from which we extracted sub-indicators:

- nutritional standards;

- availability of micronutrients;

- protein quality;

- food security. 
We calculated the values of the selected sub-indicators for the period 2012-2018 and achieved the optimized geometric mean. Then, we used the relative distance method to rank the European countries in the year 2018, compared to the highest level held by France.

After the hierarchy, an optimized global index was created average arithmetic type arithmetic mean for each criterion: affordability, availability, quality and safety. Concurrently, a ranking of the countries in Europe was made according to the optimized global index, and at the end, Romania's position towards the European countries was determined at the level of 2018.

\section{Results and discussions}

Starting from the methodology mentioned above, we performed a statistical approach to determine an optimized index, by which we built an aggregate index at the GFSI index, made up of the first four significant contributors to the sub-indicator, and not those with the greatest share in its realization.

Thus, for the Food affordability criterion, the share of this in GFSI is $40 \%$, and within it the structure presents the first 4 most important sub-indicators: food consumption as a share of household expenditures and gross domestic product per capita, with a weight of $22.2 \%$, followed by the share of the population below the global poverty line by $20.2 \%$ and the presence of the food safety programs by $14.1 \%$,

In fact we noticed that for the whole series analyzed from 2012 to 2018 (table no. 9) the most of the achievements are the consumption of food as a share of household expenditures, the share of the population below the global poverty line, the presence of food security programs, access to finance for farmers. Therefore, we have determined that from the first criterion of food affordability, these indicators are taken into account and entered into the aggregate index, respectively the optimized global index.

Table no. 9: Determining the contribution of each sub-indicator to the food affordability criterion

\begin{tabular}{|l|r|r|r|r|r|r|r|r|r|r|r|r|r|r|r|r|}
\hline Affordability & \multicolumn{2}{|c|}{2012} & \multicolumn{2}{|c|}{2013} & \multicolumn{2}{l|}{2014} & 2015 & 2016 & 2017 & 2018 \\
\hline 1.1 & $\mathbf{2 2 , 2}$ & 50 & 11,08 & 50 & 11,17 & 50 & 10,99 & 50 & 10,99 & 50 & 11,06 & 43 & 9,61 & 43 & 9,59 \\
\hline 1.2 & 20,2 & 99 & 20,00 & 99 & 19,92 & 99 & 19,92 & 99 & 19,92 & 99 & 19,92 & 99 & 20,02 & 99 & 20,02 \\
\hline 1.3 & 22,2 & 13 & 2,97 & 14 & 3,17 & 15 & 3,35 & 16 & 3,46 & 17 & 3,69 & 18 & 3,93 & 20 & 4,35 \\
\hline 1.4 & 10,1 & 81 & 8,17 & 79 & 8,01 & 82 & 8,25 & 82 & 8,25 & 81 & 8,21 & 84 & 8,46 & 82 & 8,27 \\
\hline 1.5 & 14,1 & 100 & 14,10 & 100 & 14,10 & 100 & 14,10 & 100 & 14,10 & 100 & 14,10 & 100 & 14,10 & 100 & 14,10 \\
\hline 1.6 & 11,1 & 100 & 11,10 & 100 & 11,10 & 100 & 11,10 & 100 & 11,10 & 100 & 11,10 & 100 & 11,10 & 100 & 11,10 \\
\hline
\end{tabular}

Note: With red are the actual values calculated for the most contributing indicators (67.6\%); With blue are those who were eliminated (32.4\%).

The Food availability criterion is $44 \%$ in GFSI, and within it the structure presents the top 4 most important contributors as the supply sufficiency indicators with a weight of $23.4 \%$, the agricultural output volatility with a weight of $13.5 \%$, followed by agricultural infrastructure and food loss both by $12.6 \%$. In the survey, we have noticed that for all the analyzed series from 2012 to 2018 (see table no. 10), all these indicators, which brought the 
most achievements, are in the following sequence: supply sufficiency, food loss, agricultural production volatility and infrastructure agricultural. Therefore, we have determined that on the basis of these criteria these indicators have to be taken into account and entered in the aggregate index.

Table no. 10: Determining the contribution of each sub-indicator to the food availability criterion

\begin{tabular}{|c|c|c|c|c|c|c|c|c|c|c|c|c|c|c|c|}
\hline Availability & & 2012 & & 2013 & & 2014 & & 2015 & & 2016 & & 2017 & & 2018 & \\
\hline 2.1 & 23,4 & 88 & 20,57 & 90 & 20,94 & 90 & 20,94 & 86 & 20,03 & 85 & 19,91 & 86 & 20,03 & 86 & 20,03 \\
\hline 2.2 & 8,1 & 13 & 1,01 & 13 & 1,01 & 25 & 2,03 & 0 & 0,00 & 25 & 2,03 & 25 & 2,03 & 25 & 2,03 \\
\hline 2.3 & 12,6 & 61 & 7,70 & 61 & 7,70 & 61 & 7,70 & 61 & 7,70 & 61 & 7,70 & 52 & 6,54 & 52 & 6,54 \\
\hline 2.4 & 13,5 & 66 & 8,87 & 66 & 8,87 & 68 & 9,21 & 68 & 9,11 & 65 & 8,78 & 68 & 9,22 & 69 & 9,34 \\
\hline 2.5 & 9,9 & 56 & 5,50 & 56 & 5,50 & 67 & 6,60 & 67 & 6,60 & 72 & 7,15 & 59 & 5,82 & 65 & 6,41 \\
\hline 2.6 & 9,9 & 25 & 2,48 & 25 & 2,48 & 25 & 2,48 & 25 & 2,48 & 25 & 2,48 & 25 & 2,48 & 25 & 2,48 \\
\hline 2.7 & 9,9 & 65 & 6,40 & 63 & 6,23 & 67 & 6,61 & 73 & 7,19 & 89 & 8,81 & 79 & 7,85 & 100 & 9,90 \\
\hline 2.8 & 12,6 & 86 & 10,86 & 86 & 10,86 & 86 & 10,86 & 95 & 11,91 & 95 & 11,91 & 95 & 12,01 & \begin{tabular}{l|l|}
95 & \\
\end{tabular} & 12,01 \\
\hline
\end{tabular}

Note: With red are the actual values calculated for the most contributing indicators $(62.1 \%)$; With blue are those who were eliminated (37.8\%).

The Quality and safety food criterion is $16 \%$ in the GFSI, and within it the structure presents the first 4 most important contributors as indicators of the availability of micronutrients with a weight of $25.40 \%$ then the quality of the proteins with a weight of $23.7 \%$ followed by the sub-indicator of dietary diversification by $20.3 \%$ and food safety by $16.9 \%$. As a result of the research, we noticed that for the whole series analyzed from 2012 to 2018 (see table no. 11), the indicators that brought the most achievements are: protein quality, food safety availability of micronutrients, nutritional standards.

Therefore, we have determined that the third criterion should be taken into account and added to the aggregate index, respectively the optimized global index.

Table no. 11: Determining the contribution of each sub-indicator to the food quality and safety criterion

\begin{tabular}{|c|c|c|c|c|c|c|c|c|c|c|c|c|c|c|c|}
\hline \multicolumn{2}{|c|}{ Quality and safety } & \multicolumn{2}{|l|}{2012} & \multicolumn{2}{|l|}{2013} & \multicolumn{2}{|l|}{2014} & \multicolumn{2}{|l|}{2015} & \multicolumn{2}{|l|}{2016} & \multicolumn{2}{|l|}{2017} & \multicolumn{2}{|l|}{2018} \\
\hline 3.1 & 0,30 & 65 & 13,17 & 65 & 13,17 & 64 & 13,05 & 63 & 12,69 & 63 & 12,69 & 63 & 12,69 & 60 & 12,24 \\
\hline 3.2 &, 60 & 100 & 13,60 & 100 & 13,60 & 100 & 13,60 & 100 & 13,60 & 100 & 13,60 & 100 & 13,60 & 100 & 13,60 \\
\hline 3.3 & 40 & 56 & 14,20 & 56 & 14,20 & 56 & 14,20 & 56 & 14,20 & 56 & 14,20 & 56 & 14,20 & 56 & 14,20 \\
\hline 3.4 & 23,70 & 77 & 18,15 & 73 & 17,32 & 73 & 17,21 & 71 & 16,92 & 71 & 16,92 & 71 & 16,92 & 66 & 15,57 \\
\hline 3.5 & 16,90 & 100 & 16,90 & 100 & 16,90 & 100 & 16,90 & 100 & 16,90 & 100 & 16,90 & 100 & 16,90 & 100 & 16,9 \\
\hline
\end{tabular}

Note: With red are the actual values calculated for the most contributing indicators (79.7\%); With blue are those who were eliminated (20.3\%).

After establishing the four sub-indicators for each criterion, we proceeded to aggregate them on each criterion by calculating the optimized geometric mean at each level and we noticed in the new construction that the individual indicators fluctuate by decreasing their volatility (see table no. 12). 
Table no. 12: Construction of the GFSI optimized global index

\begin{tabular}{|c|c|c|c|c|c|c|c|c|c|c|c|c|c|c|c|}
\hline \multirow{2}{*}{\begin{tabular}{|l}
1.1 \\
\end{tabular}} & \multirow[b]{2}{*}{22,2} & \multicolumn{2}{|l|}{2012} & \multicolumn{2}{|l|}{2013} & \multicolumn{2}{|l|}{2014} & \multicolumn{2}{|l|}{2015} & \multicolumn{2}{|l|}{2016} & \multicolumn{2}{|l|}{2017} & \multicolumn{2}{|l|}{2018} \\
\hline & & 50 & 11,08 & 50 & 11,17 & 50 & 10,99 & 50 & 10,99 & 50 & 11,06 & 43 & 9,61 & 43 & 1,1 \\
\hline 1.2 & 20,2 & 99 & 20,00 & 99 & 19,92 & 99 & 19,92 & 99 & 19,92 & 99 & \begin{tabular}{|l|}
19,92 \\
\end{tabular} & 99 & 20,02 & 99 & 20,0 \\
\hline 1.3 & 22,2 & 13 & 7 & 14 & 3,17 & 15 & 3,35 & 16 & 3,46 & 17 & 3,69 & 18 & 3,93 & 20 & 7,0 \\
\hline 1.4 & 10,1 & 81 & 8,17 & 79 & 8,01 & 82 & 8,25 & 82 & 8,25 & 81 & 8,21 & 84 & 8,46 & 82 & 8,2 \\
\hline 1.5 & 14,1 & 100 & 14,10 & 100 & 14,10 & 100 & 14,10 & 100 & 14,10 & 100 & 14,10 & 100 & 14,10 & 100 & 14, \\
\hline 1.6 & 11,1 & 100 & 11,10 & 100 & 11,10 & 100 & 11,10 & 100 & 11,10 & 100 & 11,10 & 100 & 11,10 & 100 & 11, \\
\hline \multicolumn{2}{|c|}{$40 \%$ affordability in GFSI } & 26,84 & 22,51 & 26,84 & 22,51 & 27,36 & 22,44 & 27,08 & 22,44 & 27,76 & 22,47 & 27,16 & 21,93 & 27,56 & 21,92 \\
\hline \multicolumn{3}{|c|}{ Geometric optimized mean } & 13,65 & & 13,66 & & 13,60 & & 13,60 & & 13,63 & & 13,17 & & 13,17 \\
\hline \multicolumn{3}{|c|}{ Geometric optimized mean } & 61,39 & & 61,90 & & 62,61 & & 62,95 & & 63,61 & & 63,19 & & 64,0 \\
\hline & & \multicolumn{2}{|l|}{2012} & \multicolumn{2}{|l|}{2013} & \multicolumn{2}{|l|}{2014} & \multicolumn{2}{|l|}{2015} & \multicolumn{2}{|l|}{2016} & \multicolumn{2}{|l|}{2017} & \multicolumn{2}{|l|}{2018} \\
\hline 2.1 & 23,4 & 88 & 20,57 & 90 & 20,94 & 90 & 20,94 & 86 & 20,03 & 85 & 19,91 & 86 & 20,03 & 86 & 20,0 \\
\hline 2.2 & 8,1 & 13 & 1,01 & 13 & 1,01 & 25 & 2,03 & 0 & 0,00 & 25 & 2,03 & 25 & 2,03 & 25 & 2,0 \\
\hline 2.3 & 12,6 & 61 & 7,70 & 61 & 7,70 & 61 & 7,70 & 61 & 7,70 & 61 & 7,70 & 52 & 6,54 & 52 & 6,5 \\
\hline 2.4 & 13,5 & 66 & 8,87 & 66 & 8,87 & 68 & 9,21 & 68 & 9,11 & 65 & 8,78 & 68 & 9,22 & 69 & 9,3 \\
\hline 2.5 & 9,9 & 56 & 5,50 & 56 & 5,50 & 67 & 6,60 & 67 & 6,60 & 72 & 7,15 & 59 & 5,82 & 65 & 6,4 \\
\hline 2.6 & 9,9 & 25 & 2,48 & 25 & 2,48 & 25 & 2,48 & 25 & 2,48 & 25 & 2,48 & 25 & 2,48 & 25 & 2,4 \\
\hline 2.7 & 9,9 & 65 & 6,40 & 63 & 6,23 & 67 & 6,61 & 73 & 7,19 & 89 & 8,81 & 79 & 7,85 & 100 & 9,9 \\
\hline 2.8 & 12,6 & 86 & 10,86 & 86 & 10,86 & 86 & 10,86 & 95 & 11,91 & 95 & 11,91 & 95 & 12,01 & 95 & 12,01 \\
\hline \multicolumn{2}{|c|}{$44 \%$ availability in GFSI } & 29,52 & 24,76 & 29,52 & 24,76 & 30,10 & 24,69 & 29,79 & 24,69 & 30,54 & 24,72 & 29,88 & 24,13 & 30,32 & 24,1 \\
\hline & & \multicolumn{2}{|l|}{2012} & \multicolumn{2}{|l|}{2013} & \multicolumn{2}{|l|}{2014} & \multicolumn{2}{|l|}{2015} & \multicolumn{2}{|l|}{2016} & \multicolumn{2}{|l|}{2017} & \multicolumn{2}{|l|}{2018} \\
\hline 3.1 & 20,30 & 65 & 13,17 & 65 & 13,17 & 64 & 13,05 & 63 & 12,69 & 63 & 12,69 & 63 & 12,69 & 60 & 12,2 \\
\hline 3.2 & 13,60 & 100 & 13,60 & 100 & 13,60 & 100 & 13,60 & 100 & 13,60 & 100 & 13,60 & 100 & 13,60 & 100 & 13,6 \\
\hline 3.3 & 25,40 & 56 & 14,20 & 56 & 14,20 & 56 & 14,20 & 56 & 14,20 & 56 & 14,20 & 56 & 14,20 & 56 & 14,2 \\
\hline 3.4 & 23,70 & 77 & 18,15 & 73 & 17,32 & 73 & 17,21 & 71 & 16,92 & 71 & 16,92 & 71 & 16,92 & 66 & 15,57 \\
\hline 3.5 & 16,90 & 100 & 16,90 & 100 & 16,90 & 100 & 16,90 & 100 & 16,90 & 100 & 16,90 & 100 & 16,90 & 100 & 16,90 \\
\hline $16 \%$ & afety & 10,74 & 9,00 & 10,74 & 9,01 & 10,94 & 8,98 & 10,83 & 8,98 & 11,10 & 8,99 & 10,86 & 8,77 & 11,02 & 8,77 \\
\hline GFSI & & 67,1 & & 67,1 & & 68,4 & & 67,7 & & 69,4 & & 67,9 & & 68,9 & \\
\hline Aggr & & & 56,28 & & 56,28 & & 56,11 & & 56,11 & & 56,17 & & 54,83 & & 54,8 \\
\hline
\end{tabular}

The data presented in table no. 12 with reds are the sub-indicators that were taken into account in construction the optimized global index, and blue ones are the values of subindicators that were not used to build the optimized global index.

Comparing to the food affordability criterion, the optimized geometric mean, we can see that the difference between the maximal - minimum extremes is 2.61 points in the optimized geometric mean using all sub-indicators of the food affordability criterion, while for the optimized average of the four elected indicators and calculate we notice a gap difference of 0.49 points. Under these circumstances, we may consider that this criterion is valid and leads us to the correct applicable results.

In the next stage of research, we used the relative distance method applied to the four aggregate index of each affordability, availability and food quality and safety criterion, and we set the hierarchy of European countries on each criterion for 2018.

In the new context, we have determined the arithmetic mean value of the points accumulated by each European state for the year 2018, and in this sense we have achieved a new result consisting of a new hierarchy of countries according to the gap with the best 
performance (e.g.: France - 2.33 points) and the last ranked hierarchy (e.g. Serbia - 15.67 hierarchical points).

Thus, we could achieve the ranking of the countries in Europe according to the GFSI optimized index taking reference year 2018 (figure no. 1).

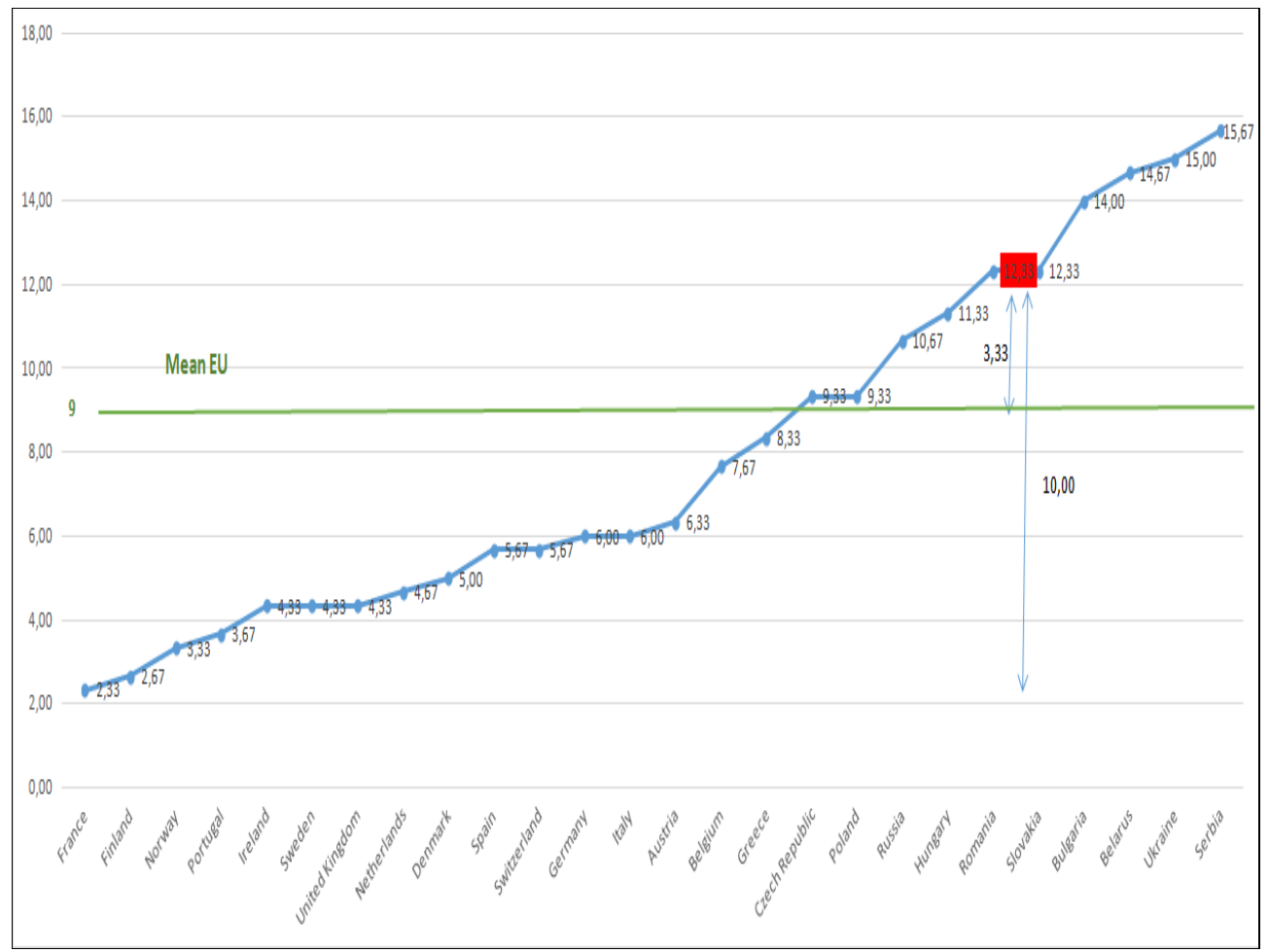

Figure no. 1: The ranking of countries in Europe according $t$ o the GFSI optimized global index for 2018

Regarding the ranking of the countries in Europe according to the GFSI optimized index for 2018 (figure no. 1), we can say about Romania that:

- holds the 17th hierarchical rank with a calculated score for the four indicators of 12.33 points;

- is at 3.33 points of the average of the 26 countries in Europe;

- is at 10 points of first rank: France.

\section{Conclusions}

The Global Food Security Index (GFSI) is the one that examines food security, comprehensive in three international dimensions, namely affordability, availability and food quality and safety. It is used as a benchmark for government policy on food security and is a research tool for academia and investors. 
The article contains an analysis of the food security of the European countries using the global food security index where it can see an interesting hierarchy of the countries as well as the position of Romania in this respect.

The hierarchy could be achieved by constructing an aggregate index, between the indices presented or only some of them, motivating the construction as an index built as an optimized geometric mean.

We have built an optimized global index using the relative distance method that allows to observe the relative distance of each country to the country that records the highest level in Europe.

The optimized global food security index is relevant in its analysis as it only includes subindicators that contribute significantly, and its refining has gone through mathematical processing that has led to a more relevant hierarchy of these countries.

From the analysis of the evolution of the variables considered in this research, it can be seen that, although in Romania food security is achieved, there are some components that need to be improved: Gross domestic product per capita, agricultural infrastructure and agricultural production volatility.

In conclusion, we can say that in Romania there is a favorable environment for food security and sufficient sources of financing for farmers. This is due to the authorities concern to raise food standards, the presence of a nutrition improvement strategy and the collection of data on nutritional deficiencies. Romania has sufficient capacity for storing food, has a well-developed network of food shops, and the population has access to the drinking water sources.

A direction in the future research could be to develop a new GFSI index model by integrating new elements into a predicted and simulated construction at least on data series as for those investigated at this time

\section{References}

Andronie, M. 2015. Ensuring Security of Data Used by Economic Organizations for Decision Support. In: 21st International Conference The Knowledge-Based Organization, Book Series: Knowledge Based Organization International Conference. 11-13 ${ }^{\text {th }}$ June 2015, Sibiu, Romania. Vol.21 pp.770-775, DOI: 10.1515/kbo-2015-0130.

Brata, A.M., 2008. Alimentary safety: differencies between developed and deloping countries. Annals of the University of Oradea, Economic Science, 1, pp.219-224. [online] Available at: <http://steconomice.uoradea.ro/anale/volume/2008/v1 international-business-and-european-integration/040.pdf $>$.

Brooks, K. and Place, F., 2019. Global food systems: Can foresight learn from hindsight?, Global Food Security, 20(1), pp.66-71.

Chirimbu, S. and Burda, A., 2013. Modern Approaches on Defining Food Quality on the EU Market. Annals of Spiru Haret University. Economic Series, 1(13), pp.57-65.

Cook, J.T. and Frank, D.A., 2008. Food security, poverty, and human development in the United States. Annals of the New York Academy of Sciences, 1136, pp.193-209. 
Drăgoi, M.C., Andrei, J.V., Mieilă, M., Panait, M., Dobrotă, C.E. and Lădaru, R.G., 2018. Food Safety and Security in Romania - An Econometric Analysis in the Context of National Agricultural Paradigm Transformation. Amfiteatru Economic, 20(47), pp. 134-150.

EU Delegation to Ethiopia, 2018. Assessing the root causes of recurring food insecurity in Ethiopia. [pdf] Available at: <https://europa.eu/capacity4dev/resilience_ethiopia/ documents/assessing-root-causes-recurring-food-insecurity-ethiopia-eu-delegationethiopia-2018> [Accessed 29.10. 2018].

Government of Malta, 2018. Food and Nutrition Policy and Action Plan for Malta 2015 2020. [online] Available at: <https://deputyprimeminister.gov.mt/en/documents/ national-healthstrategies/fnap_en.pdf> [Accessed 21.11. 2018].

Gurgu, E., 2011. Agricultura mondiala si alimentatia in lume. Economie internațională. Relații economice internaţionale. București: Editura Fundației România de Mâine.

Hampton, T., 2007. Food insecurity harms health, well-being of millions in the United States. JAMA, 298, pp.1851-1853.

Hanning, I.B., O’Bryan, C.A., Crandall, P.G. and Ricke, S.C., 2012. Food Safety and Food Security. Nature Education Knowledge, 3(10), p.9.

Jeroen, C., 2015. Food security governance: A systematic literature review. [online] Available at: <https://researchgate.net/publication/263747877_Food_security_ governance_A_systematic_literature_review> [Accessed 10.11.2018].

Kaiser, L., Chaidez, V., Algert, S., Horowitz, M., Martin, A., Mendoza, C. et al., 2015. Food Resource Management Education with SNAP Participation Improves Food Security. Journal of Nutrition Education and Behavior, 47(4), pp.374-378. DOI: 10.1016/j.jneb.2015.01.012.

King, T., Cole, M., Farber, J.M., Eisenbrand, G., Zabaras, D., Fox, E.M. and Hill, J.P., 2017. Food safety for food security: Relationship between global megatrends and developments in food safety. Trends in Food Science \& Technology, 68, pp.160-175.

Kristjansson, B., Petticrew, M., MacDonald, B., Krasevec, J., Jansen, L., Greenhalgh, T., Wells, G. A. et al., 2007. School feeding for improving the physical and psychosocial health of disadvantaged students. Cochrane Database of Systematic Reviews, 1, Art No. CD004676. DOI: 10.1002/14651858.CD004676.

Mustata, M.A., Andronie, M. and Barbalata, S., 2014. Exploring Alternative Ways of Teaching Metacognitive and Epistemic Skills. In: Proceedings of the 10th International Scientific Conference on eLearning and Software for Education: Let's Build the Future Through Learning Innovation. Bucharest, April 24-25, 2014. Bucharest: „Carol I” National Defense University Press. vol.1, pp.350-355.

Post, D.L., 2006. The precautionary principle and risk assessment in international food safety: how the world trade organization influences standards. Risk Analysis, 26(5), pp.1259-1273.

Rădulescu, C.V. and Ioan, I., 2011. Air quality in Romania. Main pollutant emissions and financing possibilities for emission reduction. Annals of Spiru Haret University. Economic Series, 1(11), pp.165-173

Scott, E., 2003. Food safety and foodborne disease in 21 st century homes. The Canadian Journal of Infectious Diseases, 14(5), pp.277-280. 
Strauss, D.M., 2014. Food Security and Safety. In: K. Ludlow, S. Smyth and J. FalckZepeda, eds. Socio-Economic Considerations in Biotechnology Regulation. New York: Springer. pp.109-123.

Stroe, C., Cojanu, S.-F. and Militaru, E., 2010. The profile of Romanian consumer and how the economic crisis impacts the consumer mentality. Annals of Spiru Haret University. Economic Series, 1(10), pp.29-36.

Șerban, M., Hurloiu, L.R., Ștefan, R.M. and Hurloiu, I.I., 2015, Situations reffering to the organization, classification and management of economic data. Annals of Spiru Haret University, Economic Series, 15(3), pp.31-37.

The Economist Intelligence Unit, 2018. Global Food Security Index 2018. [online] Available at: <https://foodsecurityindex.eiu.com/> [Accessed 10.11. 2018].

The United Nations, 2018. Sustainable Development Solutions Network. Agricultural transformation pathways initiative. [online] Available at: <http://unsdsn.org/what-wedo/solution-initiatives/national-transformation-pathways-for-sustainable-agricultureand-food-systems/> [Accessed 10.11. 2018].

Uță, C. 2009. Restructuring of The Institutional Training of Adults. Annals of Spiru Haret University. Economic Series, 9(1), pp.29-36

Zanin, L.M., da Cunha, D.T., de Rosso, V.V., Capriles, V.D. and Stedefeldt, E., 2017. Knowledge, attitudes and practices of food handlers in food safety: An integrative review. Food Research International, 100(1), pp.53-62. 